\title{
Neither a Conscript Army nor an All-Volunteer Force: Emerging recruiting models
}

\author{
Eyal Ben-Ari, Elisheva Rosman and Eitan Shamir
}

\section{Introduction}

Most academic and professional military debates about the advantages and disadvantages of force composition (and therefore of recruitment and retention) posit a dichotomy between the conscription and the all-volunteer models. ${ }^{1}$ In this article, we argue that a new model maximizing the benefits of the two systems - providing a necessary mass of force and specialized military professionals - has emerged in Israel. Moreover, we contend that a close scrutiny of other countries reveals similar, if hitherto limited, moves in other militaries. While some countries such as Finland or South Korea have maintained conscription along the classic lines of a mass army, other cases such as Sweden or Lithuania maintain two parallel systems by decreasing the numbers of conscripts and strengthening a corresponding volunteer system. In contrast, Israel has experimented with and adapted its model of mandatory military service by "grafting" onto conscription a set of arrangements that allow it to also to enjoy many of the benefits of a fully-fledged voluntary force centered on military professionalism.

While Israel's universal conscription has never really been truly universal (and is becoming less so), for many groups in the country, the Israel Defence Forces (IDF) still embodies the ethos of being a "People's Army". Moreover, the country preserves compulsory military service (now 32 months for men, 24 months for women) despite evidence that volunteer forces are more cost-effective in terms of outlays for training and personnel (Arad, 2010).

Why then, does Israel maintain conscription despite its inbuilt inequalities and costs? We contend that in order to meet its security challenges and the personnel needs derived from the answers to these challenges, what has evolved is a form of selective conscription integrating 
into a sometimes-bewildering array of organizational routes and roles involving different lengths of actual service (often combining pre-enlistment courses and post-conscription service as quasi-regulars), pecuniary rewards (depending on nearness to combat), professional development, and formal promotion prospects and possibilities in the civilian workforce. Furthermore, the design of this mode of conscription represents an attempt to meet domestic social, economic and political demands that have developed in Israel during the past three or four decades. In other words, this is an adaptive system since it allows the military to maintain its image of embodying the national ethos, adhering to economic constraints and addressing the multiple motivations of potential recruits while meeting the professional military demands of today's armed conflicts. ${ }^{2}$

The IDF has a three-tier force structure comprised of conscripts, regulars and reserves. Recent decades have witnessed notable changes with considerable downsizing of the reserves (along with increasing material rewards to those who remain in service) (Levy, 2011; Rein and BenAri, forthcoming), coupled with a reform of the component of regulars (creating different types of contracts and lengths of service) (Safrai, 2019). What is perhaps less publicly prominent but perhaps no less significant are the organizational transformations that have occurred in the conscription model. The importance of changes to conscription, moreover, lies in the fact that in Israel virtually all regulars and reservists (enlisted troops, NCOs and officers) have served as conscripts and the fact that all members of Israel's Internal Security Agency, the Mossad and the police have undergone compulsory military service.

The contemporary model of conscription is very different from the form it took until the late 1980s. As mentioned, today's recruits face a multiplicity of possibilities tied to their future roles, units and positions. Selective conscription is encased in a wider hybrid structure that combines elements of professional and militia models (Cohen, 2010b). But this form of recruitment is neither an all-volunteer force nor a universal mandatory conscription force, nor is it a simple mix of the two in the sense that one segment of the force based on volunteers is 
juxtaposed with a conscript-based one. Naming Israel's model as hybrid is not enough since this term or its synonyms - mixture, amalgam or fusion - misses the logic, the organizing principles by which it is put together and adapts to changing operational and social changes. We suggest that a fruitful metaphor for understanding the particular form of adaptive hybrid system that has emerged in Israel is that of "grafting" since onto conscription have been implanted multiple arrangements that become "organically" interrelated with it. This metaphor also illuminates how ongoing changes can be likened to "pruning" the limbs of a tree. Finally, we suggest this metaphor to shed light on the fact that this type of conscription is a "live" model in the sense that changes are constantly being made to it; enabling it to adapt. In other words, the conscription model is an emergent one that historically was never fullydesigned with an overall picture in mind and therefore did not develop uni-directionally to emerge fully coherent. Rather, it developed over decades incrementally and piecemeal. But because the organizing principles have been in place for the past three or so decades it has been easy to attach (or detach) new practices and arrangements to the central core of conscription.

To understand this system, one must take into account that human resources (HR) practices are never only internal organizational matters. They carry social meanings and resonate with wider beliefs and images about the composition of the armed forces and their missions. In short, we contend that changes to the system of mandatory military service are the outcome of alterations in the way armed conflicts are waged and transformations in Israeli society (embedded as in global developments). These developments create certain expectations about how the armed forces should be trained, maintained and deployed and how they use the lethal force at their disposal. To reiterate, today's conscription system is the culmination of a series of adaptive responses undertaken by senior decision-makers to assure the continued legitimacy of the IDF and to maintain its material and symbolic support. 
It should be stressed that the paper focuses on the way the IDF as an organization addresses motivation and conscription. We therefore do not include civilian initiatives aimed at boosting motivation and conscription, such as the Acharai ("follow me") organization or various preparatory seminaries (mechinot).

In this article, our aims are conceptual and integrative. It is conceptual in that we offer a way to theorize this emergent model and its main organizing principles. It is integrative since we bring together findings and empirical data from diverse sources external studies, publicly available data and specialized reports). The scholarly importance of this study, lies in three directions: first in advancing studies of conscription around the world; second in developing a new model for analyzing the Israeli system; and third in offering a way to apply it to other conscription systems.

\section{Conscription Models}

The large inter-power and global wars that took place since the $19^{\text {th }}$ century saw the rise of conscription as the dominant model since the operational dictate was for mass armies (Lachmann, 2013). Although the end of the Cold War brought many of the industrial democracies to abolish conscription (or put it on hold) and shift towards all-volunteer forces, a number of countries have decided to maintain mandatory military service or renew it after its abolishment (Ajangiz, 2002; Boene, 2009; Haltiner and Szvircsev Tresch, 2009). At present, less than $50 \%$ of world state militaries maintain some form of conscription (Tishler and Hadad, 2011).

In the scholarly world, the majority of studies have focused on the end of conscription explaining this development as the outcome of focus pressures to reduce defense budgets with the end of the Cold War, and new operational demands such as the move to multi-country cooperation and the use of expeditionary forces. Hence, because conscripts were seen ideally as defenders of national territory in democracies and could only be sent abroad unless they 
volunteered to do so, abolishing mandatory military service was expected and seen as acceptable.

Yet some democracies have decided to continue some form of conscription (for example, Finland, Norway, Greece, South Korea, or Taiwan) or are considering reinstating it (such as Sweden and Lithuania) others are considering it (for example, France and Germany) (BBC News, 2015; Mohadin, 2018). Maintaining or renewing conscription can usually be explained, first and foremost, by the fear that abolishing conscription will impair the ability to recruit soldiers of a sufficient level to staff advanced technical roles (Bieri, 2015; Danko and Hall, 2016). Indeed, many of the democracies that have ended conscription have found it difficult to meet recruitment goals. In Sweden, for example, the decision to renew conscription to a certain extent, means that 4,000 men and women will be called up for service. They will be selected from about 13,000 young people born in 1999, who will be asked to undergo a military assessment. The 4000 selected for obligatory service are a small fraction of the potential manpower available: $4.4 \%$ of more than 90,000 Swedes who reach conscription age (BBC News).

In comparison, Israel, with its similar population size, has a cohort of about 100,000 potential conscripts every year, of whom about 60,000 are actually obligated to serve. In recent years, the IDF recruits about $65 \%$ out of the latter number, together with a few thousand volunteers (mainly from the Bedouin tribes, Israeli Arab Christians, Jews from abroad, Ultra-Orthodox Jews and recruits who receive a waiver for medical reasons but still volunteer to serve). This brings the total in practice to about 45,000 recruits annually.

An additional reason to reinstate conscription is especially pertinent to smaller countries: compulsory recruitment is necessary in order to assure a military force of a certain size (Jarvenpaa, 2016). Specifically, most of the Nordic and Baltic states see conscription as one of the measures needed to counter potential Russian threats (Bieri, 2018). A third reason centers on discourse valuing the social role of conscription in an era where loss of sense of citizenship 
and responsibility are prevalent (and some countries like France or the UK are toying with introducing some kind of mandatory national service in order to counter inter-social tensions) (Rosman, 2020). A fourth explanation is cultural (as in the case of Switzerland, Finland or Israel) where compulsory service is seen as embodying a national symbol and ethos (Bieri, 2018; Szvirczev Tresch, 2011).

Going beyond previous studies, our analysis focuses not only on the broad contours of mandatory military service, but on the actual organizational arrangements that conscription takes on. To be sure, there have always been various provisions and measures centered on conscription - say the difference in length of service between enlisted troops, NCOs and officers, between support and combat soldiers or according to military specialization. But to date, there has been no systematic study explaining these differences. In other words, we suggest opening up the "black-box" of conscription to suggest a much more fine-tuned analysis of the actual practices and arrangements of conscription. This kind of analysis can facilitate an exploration of how different arrangements answer different (often contradictory or complementary) operational needs and diverse social and economic expectations.

Along these lines, this article represents the first analytical attempt to explain (within one model) the combination of operational demands and social changes that have led to the creation of today's Israeli conscription model. Previous studies (Cohen, 1999; Cohen, 2002; Cohen, 2008; Cohen, 2001), described how the relative weight of the IDF's three components was changing so that the importance of the core of standing army (comprised of regulars salaried full time volunteers - and conscripts) has gradually taken pride of place; have emphasized the tension between calls for an all-volunteer military and continuing mandatory military service; or identified the role contraction of the IDF expressed in the steady reduction of nation-building activities that are not strictly military in nature and therefore not necessitating the same number of conscripts as in the past. Other studies emphasize very general trends such as the need for recruiting the middle-class to assure the staffing of high- 
tech role. However, no one single investigation has brought all of these together. Accordingly, we use the case of Israel to say something broader about conscription systems.

\section{The System - A Description \& Principles}

The IDF's present system of recruitment is based on a number of interlocking clusters of arrangements, all of which are "grafted" onto the central core of conscription. We identify five basic organizing principles by which this model is organized: selective recruitment and exemption, early discharges, extending lengths of service, intra-military volunteering and differing material and non-material incentives. Together, these principles - and the practices derived from them - allow the IDF flexibility in using its human resources and reflecting what it values professionally and symbolically.

Selective Recruitment. Selection of potential draftees begins before conscription. To begin with, since Israel's ultra-orthodox (Haredi) and Arab citizens are legally exempt from service (although a small but slowly growing number of Haredim and an even smaller number of Arab citizens do enter compulsory military service). Added to these groups who are formally exempted, are youngsters who have medical and mental health problems, all Druze women, and Jewish women who declare that they cannot serve for religious reasons. This situation means that barely half of each cohort are actually drafted into the IDF (Cohen, 2010a; Cohen, 2010b). The data also shows a decline within those groups who are obligated by law to serve. One study showed that on average, for both men and women, of those obligated to serve by law, recruitment percentage for service was 75\% in 1990 versus 65\% in 2017 (Even and Hadad, 2019). That said, studies examining motivation to serve, found no major change in motivational levels during the same time period (Rivnai Bahir and Avidar, 2017). In other words, motivational levels remained similar, while the actual percentage of conscripts out of those officially recruited were significantly reduced. This reduction in the percentage of actual conscripts can be explained by the change in the IDF's recruiting policy. By applying more 
rigorous standards, or adhering more strictly to existing standards, the IDF is able to excuse more candidates from service than in the past. Reasons for discharge are, for the most part, physical or mental health conditions and criminal background. It is not that there is a shortage of willing recruits - but rather that thanks to conscription the IDF itself is able to pick and choose whom to recruit and whom to discharge. In Israel voluntary conscripts are individuals who have been exempt - say for medical reasons - but have decided to join the army and are then formally designated as conscript volunteers.

Early Discharges. A significant minority of soldiers receive early (honorable) discharges. In 2005 about twenty per cent of conscripts did not complete their full term of conscription (Arad, 2010; Cohen, 2008). By 2015 the numbers grew to one in six men and one in twelve women, with the main reason being mental difficulties (Bochbot, 2015). The relative ease by which individuals can obtain early discharge is related to the fact that the IDF actually has a surfeit of personnel in its rear echelons and hence it is not surprising that most of those discharged belong to rear echelon units where such a surplus is most evident. Many of these discharged draftees, moreover, belong to families facing economic welfare problems and the IDF often places them in military bases situated near their homes so that they are able to help their families, mainly by working during off-duty hours and navigating state bureaucracy for their parents.

Roni Tiargan, who has been following IDF recruiting trends more than two decades has concluded that

motivation for military service and significant service on the part of the young men and women whom the IDF regards as (at least) potential conscripts has not declined over the past two decades. At the same time, the number or percentage of Israeli teens who do not, from the perspective of the IDF, constitute a potential for military service may have increased, primarily due to demographic developments, the administrative decisions of the IDF, legislation, and other factors (Tiargan, 2015). 
Selective conscription and early discharge together then, are a mechanism for dealing with the negative implications - basically hidden unemployment [within the military ranks] - that marks conscription models and building into the system a measure of flexibility.

Elongated Lengths of Service. Attached to conscription are a large number of programs that in effect lengthen the actual time served within the IDF and hence make troops undergoing them available for deployment beyond the formally stipulated periods. These programs are designed to provide training in a plethora of specialized occupations and roles that today's IDF needs, such as the Shchakim ${ }^{3}$ and Havatzalot programs. ${ }^{4}$ These programs take place either in military or civilian settings and train recruits in such subjects as Arabic and Farsi or computer and telecommunications skills. During participation in civilian institutions (paid for by the IDF) potential recruits are not yet soldiers, but do receive a small salary from the Ministry of Defense. The IDF also runs a number of technical high-schools and is involved in programs (such as computing) in regular civilian high-schools that train future specialists. To join most of these programs, recruits must agree to lengthening their term of service between a few months and a few years. The result is that the additional periods of training are organically related the jobs conscripts take on. In addition, each year about a thousand individuals are allowed to study for an undergraduate degree (all universities in Israel are civilian) mainly in the sciences, medicine, engineering and social sciences. During their studies, summers are devoted to basic training and NCOs and Officer courses. Individuals enrolled in these programs must commit, beyond their obligatory conscription term, to a further three years of service as short-term regulars. Obtaining university degrees usually guarantees that they will be placed in corresponding military roles.

Forms of Voluntary Service. A closely interlaced principle woven into conscription and these programs is that of volunteering since assignment to many roles and units depends on potential or actual recruits coming forward freely and competing for them. Thus, for instance, draftees must volunteer and compete to be accepted to one of the elite infantry brigades and the special 
forces. Some of the special forces, such as Sayeret MATKAL, and similar top tier SOF units, necessitate a commitment on the part of every soldier of a further three years as fully salaried. During the three years soldiers will complete officer school and start a university degree. Other elite units such as the commando brigade require at least an additional one-year term as a salaried regular. Similarly, to be accepted for training as naval commanders, sailors in submarines, pilots or air-crews, individuals must sign-on for a further number of years beyond conscription (again after completing their mandatory regular service). Women who volunteer for many positions that require longer training such as one of the border defense units), along Israel's borders, the artillery, dog handlers, search and rescue teams, and many other specialized positions, are also obliged to sign on for an extra eight months in order to serve as long as their male colleagues.

Differing Pay-scales and Other Material and Non-material Incentives. To motivate, acknowledge the importance of, and retain people in voluntary positions, the IDF offers them various material and non-material incentives. For instance, there are different salaries for conscripts in combat, support and rear-echelon roles. Many units use milestones in conscripts service as opportunities to award them with special berets, insignia, or certificates. For example, at the end of their first stage of training, infantry soldiers are awarded their unit's shoulder symbol patch. Another stage affords them the right to wear their unit's beret with its distinctive color. Additional combat postings entitle soldiers to sport special pins, and other external status symbols. Soldiers recognize these signs and treat each other accordingly. Indeed, the very Hebrew term - Lochem (literally: warrior) which means combat soldier - still carries prestige in the Israeli society. Cyber soldiers, in turn, are called "cyber warriors" and members of search and rescue teams (for urban civilian centers) are labelled as "warriors". Further benefits include combat soldiers being allowed, after 21 months of service, go to and from their base in civilian clothes and use public transportation in civilian clothes. They may 
also take advantage of funds for further education upon discharge after fully completing their term of service.

In order to preserve the distinction and prestige of soldiers who engage in close combat versus those who are recently elevated to warrior status, in 2017 the IDF developed five categories to designate different "classes" of soldiers. At the top is the Front-Line Combat Soldier (Lochem Chod), a group composed of elite infantry, armor, combat engineering and other special units expected to engage the enemy offensively and in close range. Those in the second tier are defined as a Combat Soldier (Lochem) and are members of combat units such as air defense and Home Front Defense Battalions who are exposed to fire. The third tier is comprised of Operational Combat Support roles (Tomech Lechima Mivtzai) such as logistics and technical personnel who perform their duties in areas of armed conflict. The fourth tier includes Combat Support postings (Tomech Lechima) that are not involved in fighting but may under special circumstances enter zones of conflict, and finally are the Rear Echelon roles (Tafkid Oref) that include administrative functions and are stationed behind the lines (Even, 2017). Creating these designations and occasionally changing them offers another form of flexibility to the system since it allows the allocation of different kinds of prestige according to changing circumstances.

Another form of incentive involves the convertibility of military into civilian skills. In Israel, the skills and experience obtained in telecommunication and intelligence-related military posts translate easily into the civilian high-tech job market. But there are additional military roles that fit this bill. For example, after discharge, combat medics are able to accompany school trips at a nice profit (both as medics and as providers of security). Women who served as education NCOs can covert these skills to various tour guiding and education-related jobs, and drivers of heavy vehicles are often sought after by workplaces.

As is evident from this description, Israel's conscription system is characterized by different selection criteria before enlistment, a relatively lenient exemption regime during compulsory 
service, programs grafted onto compulsory service entailing different lengths in the military, and a host of voluntary routes within it marked by different incentives. Together, they provide the system a large measure of elasticity since built into each and every one of these mechanisms is the potential for change. We now move onto the operational, political, economic and social contexts within which this system has evolved and which explain its emergence.

\section{Operational Requirements}

Israel faces five major security challenges: Iran, neighboring countries, terrorist groups, semistate movements and cyber-attacks. Historically the IDF had been designed to counter two major type of threats: high-intensity conflict in the form of invasion by state militaries, and constant harassment by armed guerrilla and terror groups. Israel experienced five wars with its neighboring states between 1948 -1973. The last time its forces clashed with a state army was during the first Lebanon war 1982. Since then, due to major geostrategic shifts in the Middle East the probability of a major state-on-state war has declined sharply.

However, as this type of threat has diminished, new threats have been rising, mostly posed by various armed groups and organizations that control territories around Israel such as Hamas, Hizballah and other Islamic movements. These threats have developed from being mere nuisances into strategic threats due to the support provided by Iran, a regional power that does not share a border with Israel.

As a result, the Israeli military has had to adapt itself to a range of new threats while retaining its core capability to fight conventional high-intensity battles. Operationally, the most serious threat are the thousands of missiles located in Gaza and Lebanon that are aimed at Israel's population centers. Next are the unknown number of offensive tunnels capable of delivering armed militants into Israel's territory in a surprise attack (both in the south and the north). In addition, the Israeli military must be prepared for a Palestinian popular uprising in the 
territories, as well as terror attacks carried out by various terror groups. And, in case the conflict with Iran escalates, Israel should be able to strike as far as Iran. Finally, Israel is exposed to constant attacks through the cyber domain (Barak, Sheniak, and Shapira, 2020; Freilich, 2018).

To meet these diverse operational challenges the IDF has made some significant doctrinal and organizational transformations. Since Israel still faces the prospect of a large war, there remains a need for some kind of mass of troops and thus downsizing formations has been accompanied by the augmentation of others (along with the significant increases in firepower). These increases, in turn, are based on a host military of occupations that necessitate rather lengthy periods of training and specialization in a variety of platforms. No less important, despite overall downscaling, some units have enjoyed astounding organizational growth. These units can be classified by into a number of categories. First are the intelligence, anti-missile, telecommunications, cyber and drone units that have all seen an almost explosive enlargement, that has also necessitated highly skilled soldiers (Rodman, 2017; Baram, 2017). As in the Nordic countries (Jarvenpaa, 2016), the IDF has made concentrated efforts to encourage conscripts with requisite potential in the IT-related areas to undertake such roles. Similarly, the emergence of complex cooperation and coordination among special operations forces, the air force, intelligence arms and civilian security actors has required the integration of troops with advanced competences and know-how (Shamir and Ben-Ari, 2018).

One example of this trend is the formation of a new unit, "the multidimensional unit", dubbed the "Ghost" (re'efaim) unit. The unit was established in 2019 to serve as a laboratory for combat technological experimentation and combines the capabilities of infantry, engineering, anti-tank warfare, air and intelligence. Its purpose is to find ways to create synergies between the different disciplines and capabilities (Limor, 2020).

Second, the Home Front Command, charged with aiding national and local government bodies and the needs of the civilian population during missile attacks or emergencies, has also seen 
very significant expansion (Sher et al. 2011). While elements of this command have existed for decades, since 2006 it has been radically enlarged, upgraded and trained. Its units include search and rescue battalions, logistics elements, offices supporting local governments, or units providing information to civilian populations. This vast structure is staffed primarily by conscripts and reservists and represents another requirement for a substantial quantity of troops.

A third category of growth with its own form of expertise involves the processes by which the IDF, like all the armed forces of the democracies, experienced increasing scrutiny and public intervention in its internal affairs (by political, judicial or media actors and social movements) (Shaw, 2005; Levy, 2012). To adapt to this external monitoring the military has created new organizational structures or augmented older ones. Here are included the IDF operational military law centers (Cohen and Ben-Ari, 2015) or the media relations units (Shavit, 2016). For example, based on journalistic accounts, during the decade between 2000 and 2009, in the IDF's Military Advocate General (and especially its division for international law) the number of officers grew from five to thirty five (Haaretz 22 January 2009) - surely the largest, in relative terms, growth of any military unit in Israel during this time. This system is staffed by officers who have studied at universities before becoming conscripts and then serve as shortterm regulars. In a similar manner, although the numbers are much higher, media relations functionaries in the IDF have proliferated especially since the Second Lebanon War and Operation Cast Lead. The majority of these roles are filled by conscripts who are already well versed in today's New Media. A case in point is the expansion and increasing centrality of the IDF Spokesperson in the last two decades. Today the unit maintains an active presence in the new media (Twitter, Facebook, Instagram, Telegram) in Hebrew, Arabic, English, French, Spanish, and even in Farsi.

The ever-greater differentiation and specialization of roles and units have resulted in what Sher and her colleagues (2011) call an incremental military in which older forms are combined 
with new or renewed organizational entities and which still depends on many roles filled by conscripts. Organizationally, this term centers on a process of differentiation by which an organization increases its internal complexity (by creating new organizational units or occupations) to adapt to the increasing complexity of its external environments. This situation means that along with maintaining a steady supply of soldiers, the IDF has had to cultivate a much wider skill sets and expertise than in the past and to do so efficiently and effectively. That said, the emergence of Israel's system of mandatory military service is due not only to strictly operational considerations, but also to economic considerations.

\section{Economic Aspects: The Market Army}

Since the end of the Cold War, policy-makers in all of the industrial democracies have witnessed widespread demands for more efficient, and not only effective, state institutions. Prompted by Neo-Liberal ideas, the language of productivity and value, cost accounting and quality management, or customer orientation has also been applied to the armed forces and has had a direct influence on them (Deitelhoff and Geis, 2009; Levy, 2010; Levy, 2019). These expectations have also been directed at the IDF (Levy, 2019; Safrai, 2019), with some journalists and academics asking time and again about how efficient the military is in using its material and human resources.

While scholars such as Lipschitz argue that recruitment via the market is cheaper than conscription, given the large quantity of soldiers it still needs, this is not the case in Israel (Lipschitz, 2015). From an economic perspective, the challenge for the IDF is actually how to retain control over supply and demand for personnel in a competitive market. In particular, Israel's booming high-tech sector creates fierce competition over young talent. Under the current system, Israel's best pool of young talent, both men and women, are channeled to the military in order to be assessed, recruited, selected and trained to the various demanding jobs the IDF requires. Under the current system, the IDF does not have to compete against leading 
companies that offer lucrative compensation packages to young talent, so at the moment it enjoys a monopoly over the talent market. Like all monopiles, keeping the status quo is the desired state of affairs. Therefore, the conscription model that has evolved over the years is the answer to this challenge. Indeed, maintaining mandatory service assures control over the pool of recruits that the IDF is interested in for operational (and social) needs and allows it to exempt or grant early discharge to those who do not fit its needs. This is perhaps best expressed in the explanation the former Chief-of-Staff Gadi Eisenkot used when he said that he is "not a feminist nor a chauvinist, I am only interested in winning a war" (Eichner, 2018). Yet, as we shall presently see, these words reflect a utilitarian approach to human resources and tell only part of the story.

As implied above, recruits are encased in incentive structures that help lure and retain them. To understand these structures, one must take into account how since the 1980s, Israel has turned into a market society, one based on deep cultural changes centered on the relations between individuals and institutions. The fundamental development that has come about is that soldiers have come to expect an exchange - manifested in choice and bargaining - with the army as part of what Levy and his colleagues call "contractual militarism" (Levy, LomskyFeder, and Harel, 2007). It is not surprising for instance, that the IDF markets many roles as giving conscripts an edge into later civilian occupations. In fact, as explained, many technical and mechanical roles, or drivers of heavy engineering equipment and large trucks undergo training in the IDF (and often serve extra-time as short-term regulars) with good prospects for future employment outside the army. This kind of consideration also holds for many of the high-tech occupations and units of the military that very often open up many opportunities in the civilian High-Tech sector. The recruiters in the IDF jokingly refer to this phenomenon by the Hebrew acronym of "EMILY" which translates roughly into "what is in it for me", indicating that recruits first want to know what civilian gains their military service will afford them upon discharge. 
At the same time, discourse among recruits stresses another Israeli term: "meaningful service" (sherut mashmauti) implying that in the context conscription, some positions are not very meaningful or necessary for the military and their only raison d'etre is the need to find positions for all recruits. When recruits speak of "meaningful service", and that they wish to serve in "meaningful positions, they are stating they wish to serve in military postings that supply valuable service both to the nation and to their own personal development (Gal, 2015; Tiargan, 2015; Rivnai Bahir \& Avidar, 2017). Put simply, they want to feel they are accomplishing something that furthers them personally, but also plays a part in the greater collective good. They do not want to give such a substantial portion of their time to the military without being certain this time is well-spent. Consequently, it is important to note, however, that by the bargaining between individuals and the IDF we do not refer only to elements of limited self-interest as, for instance, material considerations or benefits. Rather, we include post-material values such as self-actualization or contribution to the national collective. A good example is the questionnaire sent out to all potential conscripts asking them to list their first three preferences in regard to the unit and occupation they would like to take up from a set list they were pre-selected for. This element of granting potential conscripts a measure of choice even before being formally drafted is further expressed in the multitude of voluntary service routes open to conscripts that fit their interests and self-image. In fact, a look at the web-page of the IDF induction center (MEITAV) reveals the hundreds of roles and positions open to conscripts along with short descriptions and hints as to the necessary skills that draftees will need to master in order to be deployed in them.

The idea at base of this exchange relationship is thus that if the army allows selfactualization, then conscripts will remain in service and if it does not then they may opt-out and find their self-expression in other places (such as leisure or academic studies). And indeed, the option not to serve has become acceptable among broad swaths of the population (Perez, 2018; Livio, 2018; Weiss, 2017). More broadly, ties based on exchange are 
part of the way IDF has adapted, through multiple service routes, to multiple motivations centered in individuals. To be sure, not all soldiers are satisfied with their placement nor with the actual work their roles involves, but the point is that the military makes a sustained effort to meet their choices and portrays itself accordingly to public expectations of a much more contractual relationship with conscripts.

Many of these programs and routes - as the contractual exchange - could easily suit allvolunteer forces but the fact that they have been integrated "organically" into a conscript system hints at yet other reasons for continuing mandatory military service that go beyond cost-effectiveness or meeting individual needs and motivations.

\section{A People's Army: Social Expectations and The Republican Ethos}

Historically, the Israeli military was seen not only as a defender of the country, but as a central symbol of the nation-state and as a melting pot - the veritable "People's Army" (Cohen 2010b; Cohen, 2010). In addition, for long periods the IDF was widely viewed as a mechanism for social change and conscription understood as a route for gaining full citizenship, and belonging to the political collective. Indeed, for large parts of society it is still so (Ben-Porat, 2012; Peled, 2012). The practices and arrangements of today's conscription system continue to resonate with these themes albeit in somewhat changed forms (Rosman, 2020).

Representativeness and fairness. The first theme centered on recruitment involves the IDF portraying itself not as statistically representative of Israeli society but nevertheless as reflecting a wide spectrum of groups belonging to it. A perusal of the old and new media reveals unending articles about soldiers who come from diverse social groups, be they new immigrants, Moslem, ultra-orthodox, women, Christians, or from disadvantaged backgrounds. Since, the IDF demographic composition does not actually reflect that of the wider Israeli population, we read these reports as attempts by the army to offer a picture of internal diversity, of at the very least hosting some representatives of these diverse groups. 
Accordingly, the slide show at the top of the IDF website as well as other reports by IDF media officers all offer diverse portraits of soldiers along gender, racial, ethnic, or religious lines (Golan and Ben-Ari, 2017). While Israel is not characterized by multi-culturalism in the European sense, there are nevertheless social expectations that state institutions reflect least some external social variety (Lomsky-Feder and Ben-Ari, 2012).

Moreover, in ways similar to the Nordic and Baltic countries (Jarvenpaa, 2016; Kosonen et. al., 2019; Poutvaara and Wagener, 2011) there is broad public understanding that efforts must be made to reach as high a percentage as possible of a given cohort for mandatory conscription to be seen as fair and universal. It is for this reason that despite the economic costs, the IDF recruits many individuals who then receive an early discharge. Further to this is one aim of emphasizing the ever-expanding roles and actual promotion to commander positions of women (Golan and Ben-Ari, 2017). It is in a similar fashion that the recruitment of some people who are exempt from service because of special needs or having a criminal background should be seen.

All reports about social diversity then, underscore the inclusive nature of this armed force because in this way the theme of "universal" conscription is joined with demands for social inclusivity. Accordingly, several social projects such as supplementary Hebrew-language classes for new immigrants or Arabs joining the force are aimed not only at assuring a basic level of Hebrew for military functioning but as fulfilling a societal role of the IDF. In the NATIV program which takes place towards the end of mandatory service, conscripts undergo a course emphasizing Zionist values and are offered the possibility of converting to Judaism. In these ways, the military allows people who otherwise would not enter society as fullyacknowledged members to tell themselves (and their families) a certain story about joining Israeli society. Likewise, the "Seeing into the Distance" program (Roiem Rachok), integrates autistic youth in military postings that can be converted into skills in the civilian market (such as analyzing aerial photos, technical skills, or optics). 
Attempting integration for another - entirely different - social group, the SHACHAR programs (an acronym in Hebrew for integrating Haredi youth), allows ultra-orthodox men to serve in the IDF in frameworks constructed specifically for their religious needs. Within these programs, haredi men are separated from women, afforded separate kitchens geared to their more stringent dietary requirements and are also allowed time for religious study. Service is usually geared towards military roles that are convertible to the civilian market (electronics specialists, air-conditioning technicians, or various computer and telecommunication roles). Those men who serve in military roles that have no civilian equivalent, are able to acquire enough of a secular education while in uniform in order to achieve their matriculation certificate and return to civilian life with tools to continue their education or enter the labor force.

An entryway to citizenship. As is historically true of many democracies (Lachmann, 2013), since Israel's independence, the primary route towards full citizenship has been compulsory military service (Helman, 1997; Lomsky-Feder, 1998). Based on the classic republican contract, the idea is that citizenship is awarded those who are willing to contribute to their country and that service in the armed forces is the epitome of such an agreement given that soldiers may have to sacrifice their lives (Levy, 2012). While it is now much more legitimate than in the past not to serve, the republican ethos is nevertheless still rather potent in contemporary Israel.

Accordingly, the IDF drafts many soldiers who can be seen as financial "burdens" as is the case of individuals who need to be located near home to help their families, those with medical problems, with criminal backgrounds or draftees with special needs. By recruiting such youngsters - many of whom are posted in low-skill jobs (say in gardening, guarding, or as clerks) - the IDF allows them to complete even a shortened term of service thereby providing them an opening in civilian society. In an empirical study of five different units (LomskyFeder and Ben-Ari, 2012), found that commanders often talked about this idea, of accepting 
the burden of problematic soldiers as a way to help them become good citizens. Similarly, efforts on the part of the gay and lesbian lobbies to normalize military service for their members underscores further how conscription is perceived as a route to citizenship (Kama, 2012).

The ideologically potent link between citizenship and military service is perhaps best exemplified by public debates regarding three groups. First, are the exemptions ultra-orthodox men receive (actually a deferral until they reach a certain age) (Ben-Porat and Turner, 2008). The ultra-orthodox sector is often portrayed as one that shirks its civic duties and responsibilities at the expense of those who do serve; breaching the republican ethos (Levy, 2012; Stadler, Lomsky-Feder and Ben-Ari, 2008). In a different way, the recruitment of women is not only cost-effective but answers public calls mounted by feminist lobbies since the 1980s. Initially, the IDF bowed to the pressure of these groups, but now actively embraces the idea of women serving in almost every military role. This embrace signals burden-sharing between men and women and resonates ideas of gender equality (Harel-Shalev \& DaphnaTekoah, 2019; Lomsky-Feder and Sasson-Levy, 2019). Finally, the Arab citizens of Israel exemplify how the contract in Israel continues to be an ethno-republican one (Ben-Porat, 2012; Peled, 2012). In this way, exemption from mandatory military service provided for Arab citizens of Israel, serves as a mechanism to exclude them from perceptions of full citizenship and certain benefits such as aid in mortgages and tax reductions or discharge bonuses given only to conscripts who complete their full term of service (Rosenhek, 2012).

\section{The Model: Flexibility, Legitimation and Institutional Autonomy}

In this article we define a model centered on five organizing principles that together characterize Israel's system of compulsory military service. We argue that these principles undergird the flexibility of the system and have allowed the IDF to constantly adapt to changing circumstances. The form that the system takes on in Israel is that of a specific form 
of hybrid - a graft of diverse arrangements onto the "tree-trunk" of mandatory service. Today one can find the beginnings of such a model in other countries, but it is now a fully-fledged one only in Israel. In this section we take a step further to show how the country's conscription model is embedded in wider civil-military relations.

The IDF, like all public bodies, is a legitimacy-seeking institution since legitimacy assures continued material and non-material support for the armed forces and their institutional autonomy a recent survey shows survey that $81 \%$ Israelis trust the IDF (88\% among the Jewish population) (Limor and Koren, 2018). Legitimacy, in turn, is based on the public's willingness to accept how its armed forces internalize and behave according to social and political expectations in regard to operational matters (how it uses the violent means at its disposal), its social composition, and the way it treats its soldiers. To remain legitimate, the armed forces constantly innovate and adjust to changing circumstances and norms because to follow legitimacy is both a precondition for support and an outcome of the process (Safrai, 2018).

These adaptive moves are undertaken to assure an institution's autonomy: the discretion allowed it for managing its relations with environments, self-regulation, professional and occupational development, upkeep of expertise and leeway for action (Pion-Berlin, 1992; Rein and Ben-Ari, forthcoming). Such autonomy is especially important for armed forces since they specialize in the preparation for, and perusal of, armed conflict. Indeed, military autonomy has long been associated with the need for some kind of separate culture to nurture and control the destructive potential of military power (Croissant and Kuehn, 2009). The separateness of the military from civilian society is essential for training, education, inculcating discipline and hierarchy, and cultivating soldiers' willingness to put themselves in harm's way.

For long periods of history, the IDF enjoyed high institutional autonomy but today its autonomy is much more circumscribed than in the past. It is limited because, like many of the 
armed forces of the democracies, it has become a more transparent (open to external monitoring) and open (given multiple relations with outside entities) system. Yet as it lost some of the autonomy it enjoyed in earlier times, the Israeli military has responded by devising strategies to adapt to and manage growing interference thus maintaining internal organizational independence. It is in this light that the conscription model should be seen and as we explained, HR practices, and recruitment, retention and promotion in particular, have answered operational, economic and social challenges.

Broadly put, over the course of time the IDF has chosen to enjoy the advantages of both a volunteer military and a People's Army by piecemeal fashioning of a model that can take advantage of both. It can portray itself as a melting pot and nation-creator resonating long held beliefs and images and earns the right to choose and select whoever comes in its door (since it does not have to directly compete in the open market). In this way, through instituting HR practices centered on selective conscription, it constantly seeks to answer expectations about conscripting troops from a variety of social groups, utilizing them in an effective and efficient manner and allowing youngsters not only a choice upon recruitment but also multiple routes towards interesting and challenging positions. The seeming "price" the IDF pays for this system means that it must maintain the ethos of conscription by recruiting groups that it may be reluctant to from a strictly economic point of view, say the ultra-orthodox or individuals with criminal backgrounds. But conscripting them it answers other public expectations.

Moreover, one set of practices may actually answer more than one set of expectations. To put this point by way of example, the practice of recruiting soldiers who have family welfare problems and then discharging them early is a practice that simultaneously, answers demands about a wide as possible recruitment of a given cohort (alluding to universalism) but also minimizes their cost. Or, specific practices like drafting individual with special needs, may not be cost-effective, but answers both expectations about the military's representativeness and diversity and allows these soldiers to realize the republican ethos. 
More broadly, the multiple practices and service routes are the core of the system's flexibility because they encase talent or skill management for operational reasons within a legitimation regime that constantly adapts to societal changes. In other words, we see the system not only as one marked by a price the Israeli military pays for being "forced" to maintain conscription, as economically driven commentators would have it. Rather, through this system the IDF seeks to transmit multiple messages to its publics and constituencies - that they are taking the correct measures to meet new threats and (at the same time) meeting expectations about how to pursue armed encounters, doing so efficiently and recruiting a representative not demographically reflective population. The IDF, like all militaries, conforms to certain organizational forms and practices not only because of intrinsic instrumental efficiency per se (but they can be efficient), but because they are rewarded for doing so. They are rewarded in terms of acquiring greater legitimacy, and thereby resources and survival capacities and greater autonomy than might otherwise be the case.

Further, the flexibility of the system lies in the fact that the model is an emergent one in which its constituent parts are constantly being formalized and institutionalized and others changed and experimented with (according to security needs and social expectations). To return to the analytical metaphor we suggested earlier, this is an "organic" system in which the main trunk of the tree (conscription) maintains continuity but other elements are implanted on it (not placed beside it) so that something new is continually developing. For example, during the 1980s when the IDF had problems recruiting physicians and engineers, it instituted new programs to convey academics through conscription and then retain them afterwards. So it is with the creation of new units with special capabilities and missions that were created during the past two decades to fill special niche needs.

Our analysis of Israel's conscript system should not be taken as some rosy-eyed depiction of a totally smooth-running model. Rather there are continuing tensions built into the system. Continuing to portray itself as a Peoples' Army and basing itself formally on universal 
conscription creates social clashes. Perhaps the most overt one is the attempt to conscript ultraorthodox men, who require gender-separate units, while also retaining gender equality and opening more combat positions for women. While these roles are not necessarily mutually exclusive, they are perceived as such. Additionally, when presenting itself as promoting women and gender minorities, the IDF also must contend with allegations that allowing women in combat requires modifying physical and professional requirements that are potentially detrimental to troop-readiness. These issues cause clashes in the civilian sphere and spill over into the courts. ${ }^{5}$

\section{Is the Model Applicable to Other Countries?}

The theoretical model that we have sketched out, we suggest, may illuminate the conscription models of other countries (and possibly contribute to policy making). The model that has developed in Israel answers a set of challenges that many of the industrial democracies face: how to assure a necessary number of troops to staff units and at the same time guarantee that recruits are trained to a requisite professional military level. As explained, the utility of the theoretical model we have developed lies in explaining the organizing principles and organizational mechanisms that facilitate mobilizing a needed number of recruits (a minimal mass). In turn, this provides an adequate level of military expertise in a variety of older and newer roles, as well as maintaining the legitimacy of the armed forces by answering social expectations about how the military uses and treats the personnel Indeed, this is a problem faced by many militaries.

Analytically, what we propose is opening-up the "black-box" of conscription to offer a sustained model integrating operational and social constraints by looking at the actual practices and arrangements that mandatory military conscription entails. Analytically, then, we suggest two moves: first, seeing armies in multiple contexts that include security needs and strategic decisions on the one hand and public demands centered on how an armed force 
handles the troops it has; and second, focusing on the variety of specialized courses, promotion routes, and material and non-material incentives built into conscription. It is especially the latter focus that allows a deeper understanding of the way HR practices and arrangements are related to diverse external expectations. Accordingly, we suggest that our kind of analysis be used as a conceptual and theoretical base for examining mandatory military service in countries around the world.

Let us give some examples from the Nordic and Baltic countries since the personnel systems of their armed forces have been in turmoil since the end of the 1990s and have been marked by a range of experiments regarding staffing various units. Moreover, in all of these countries, while the armed forces have been downsized (some drastically) during the past three decades, renewed threats (primarily from Russia) have necessitated a minimal mass of troops to meet security needs. According to the Nordic countries that maintain mandatory military service are characterized as having selective conscription due to the fact that while all men (and in Norway also women) of an age are eligible for conscription, only around 10 per cent of a given cohort are actually drafted (given the present HR needs of the respective militaries) (Jarvenpaa, 2016). Moreover, all of these countries have some form of civilian national service equivalent to the military one (Kosonen et. al., 2019).

Denmark has had a system of professional units since the mid-1990s coupled with a short recruit period as a basis for enlistment. In Denmark, for instance, those drafted, are chosen on the basis of a lottery, seen and accepted as a universal mechanism for recruitment. Once drafted, conscripts usually serve different lengths of service based on whether they remain as enlisted soldiers or progress to NCO or Officers roles or specialties that necessitate longer training. Yet they are also marked by different lengths of service and hence, in Denmark, conscripts in the Hussar Regiment serve a year (and not four obligatory months) and those in the Royal Life Guards serve eight months. 
Norway, in turn, does not have a parallel system of conscripts and salaried volunteers from day one although this is true only of enlisted personnel and not officers. ${ }^{6}$ As in Israel, the country's twelve-month conscription forms the basis for later recruitment to the enlisted ranks. And again, in ways echoing Israel, conscription is rather popular since it is seen as a mechanism for attracting the brightest youths for the military's needs, and as a means for youngsters for selfimprovement and excitement before adult life starts for real. Conscription, in turn is not seen as unfair by those who are drafted, since the perception is that only the brightest are recruited and that has led, in turn, to (feminist-inspired) demand that universal conscription should include women too.

At the same time, in contrast to Israel since conscription only lasts a short twelve months, the military has concluded that it needs professional units with a higher readiness and expertise, that in order to raise the combat readiness of conscripts to staff certain positions (with long and heavy training requirements) with full-time salaried enlisted personnel. In addition, Norway pays some groups of conscripts what amounts to near-symbolic hardship allowances. Finally, and again in contrast to Israel, while in the past all officers came up through the ranks, from 2015 this system was changed into a two tier one that is more akin to the British and US armed forces.

Sweden abandoned national military service in 2006 but soon experienced problems with recruitment where career prospects as an enlisted soldier did not appeal to the Swedish youth in sufficient numbers. Although significant numbers of youths signed up for the voluntarily military training, basically for similar reasons that conscription is rather popular in Norway (such as excitement, self-improvement, or building-up their personal resumes). But since many potential recruits found other ways to achieve such goals they did not enlist. In addition, in terms of incentives since Sweden possesses highly developed universal welfare and educational systems, unlike some conscripts in Israel, Swedish recruits did not need to need to stay in the military to gain those benefits. 
Finland, in this regard, is an exception since it practices what is closest to a universal conscription for men. The country's concept of Nation in Arms, and citizen army resembles Israel in many ways. However, in contrast to Israel, national service is only a short six months for private soldiers and twelve months for officers. Because roughly eighty percent of men in a given cohort are conscripted, the selection is near universal. And like Norway and Israel, Finland awards small but symbolically significant amounts of extra pay for soldiers in tough, front-line roles.

To sum-up, our analysis suggests four clusters or analytical dimensions related to the Israeli model of conscription as a way to manage the multiple challenges of security environments and operational needs, the tension between maintaining a sufficient number of soldiers and training them to a professional level and answering public expectations. The first refers to the kinds of justifications offered by key-decision makers (and accepted to differing degrees but publics) for instituting and maintaining a certain form of mandatory military service. The second cluster relates to the specific arrangements instituted in order to answer public expectations. For example, conscripting women answers demands for gender equality or the recruitment of members of minorities meets demands for greater diversity. The third entails the element of choice built into the system to reflect a more contractual relation between the armed forces and conscripts (not only regulars). The fourth and final cluster involves the kinds of incentives (material and non-material) instituted for retaining conscripts for long periods necessary for their training and a return on the investment in this training. In addition, we have pointed out how the analytical frame we have developed can be applied to the conscription models of other countries. 


\section{References}

Ajangiz, Rafael (2002) "The European farewell to conscription?", Mjoset, Lars and Stephen van Holde (Ed.) The Comparative Study of Conscription in the Armed Forces (Comparative Social Research, Vol. 20), Emerald Group Publishing Limited, Bingley, pp. $307-333$

Arad, Boaz 2010 Israel Needs a Professional Army. Jerusalem: Jerusalem Institute for Market Research. https://www.slideshare.net/Anochi/pp-army-english-1. Accessed 10 May 2010. (Hebrew).

Barak, Oren, Amit Sheniak, and Assaf Shapira. 2020. "The shift to defence in Israel's hybrid military strategy." Journal of Strategic Studies:1-33.

Baram, Gil 2017 Israeli Defense in the Age of Cyber War. Middle East Forum, https://www.meforum.org/6399/israeli-defense-in-the-age-of-cyberwar?utm_source=Middle+East+Forum\&utm_campaign=16aa15ca47MEQ_CAMPAIGN_2016_12_04\&utm_medium=email\&utm_term=0_086cfd423c16aa15ca47-33659661\&goal=0_086cfd423c-16aa15ca47-33659661, Accessed 17 May 2020.

Battistelli, F. (1997). Peacekeeping and the Postmodern Soldier. Armed Forces and Society 25(3) pp. 467-83.

BBC News, 2017. "Sweden brings back military conscription amid Baltic tensions," BBC News (2 March, 2017), <https://www.bbc.com/news/world-europe-39140100> (accessed: August, 2020).

Ben-Porat, Guy 2012 Inward Turns: Citizenship, Solidarity, and Exclusion. In (Guy BenPorat and Eyal Ben-Ari (eds) The Contradictions of Israeli Citizenship. London: Routledge. Pp.203-21.

Ben-Porat, Guy and Brian Turner 2008 Contemporary Dilemmas of Israeli Citizenship. Citizenship Studies Vol. 12, No. 3, June 2008, 195-201 
Bieri, Mattias 2018 Military Conscription in Europe: New Relevance. ETH Zurich: Center for Security Studies. Analyses in Security Policy. No. 180.

Bochbot, Amir 2015 A Generation Used to Eased Restrictions: One of Six Men Don't Complete Military Service. Walla News. https://news.walla.co.il/item/2915365, Accessed 16 May 2020, (Hebrew).

Boene, Bernard 2009 Shifting to All-Volunteer Armed Forces in Europe: Why, How and with What Effects? Forum Sociologico 19.

https://journals.openedition.org/sociologico/347 Accessed 10 May 2020.

Cohen, Amichai and Eyal Ben-Ari 2014 Legal-advisors in the Armed Forces: Militarylawyers in the Israeli Defence Forces as Mediators, Interpreters and Arbitrators of Meaning During Operations. Journal of Political and Military Sociology. 42:125-48.

Cohen, Stuart 1995 "Israel's Defense Force: From a 'People's Army' to a 'Professional Force'", Armed Forces \& Society,. 21:237-254.

Cohen, Stuart 1999 "Military Service in Israel: No Longer a Cohesive Force”, Jewish Journal of Sociology, 39 (1999), pp. 5-23.

Cohen, Stuart 2002 "The Israel Defense Force: Continuity and Change”, Armed Forces in the Middle East: Politics and Strategy (eds. B. Rubin \& T.A. Keaney: Frank Cass, London, 2002), pp. 162-188.

Cohen, Stuart 2008 Israel and its Army: From Cohesion to Confusion (Routledge: London, 2008)

Cohen, Stuart A. 2010a Introduction. In Stuart Cohen (ed.) The New Citizen Armies: Israel's Armed Forces in Comparative Perspective. London: Routledge. Pp. 1-3.

Cohen, Stuart A. 2010b Reversing the Tide of Jewish History: Culture and the Creation of Israel's “People's Army”. In Stuart Cohen (ed.) The New Citizen Armies: Israel's Armed Forces in Comparative Perspective. London: Routledge. Pp.56-74. 
Croissant, Aurel and David Kuehn 2009 Patterns of Civilian Control of the Military in East Asia’s New Democracies. Journal of East Asian Studies 9:187-209.

Eichner, Itamar, 2018. “Eizenkot to Ministers: I don't see women being integrated in the front lines," YNET (4 Feb. 2018) <https://www.ynet.co.il/articles/0,7340,L5088225,00.html> (accessed: August 2020) [Hebrew].

Even, Shmuel, 2017. "Remuneration for Front Line Combat Soldiers in Compulsory Service,” INSS Site (28 Sep. 2017)

<https://www.inss.org.il/he/publication/\%D7\%AA\%D7\%92\%D7\%9E\%D7\%95\%D7\%9C\%D7\%9C\%D7\%95\%D7\%97\%D7\%9E\%D7\%99-\%D7\%94\%D7\%97\%D7\%95\%D7\%93\%D7\%91\%D7\%A9\%D7\%99\%D7\%A8\%D7\%95\%D7\%AA\%D7\%94\%D7\%97\%D7\%95\%D7\%91\%D7\%94-\%D7\%91\%D7\%A6\%D7\%94\%D7\%9C/> (Accessed: August 2020) [Hebrew].

Even, Shmuel and Sasson Hadad INSS Insight No. 1221, October 31, 2019.Link [Hebrew] Freilich, Charles D. 2018.Israeli National security: a new strategy for an Era of Change. Oxford University Press.

Gal, Reuven Motivation Levels for IDF Enlistment over the Years, In Elran Meir and Sheffer Gabi (ed) ,Military Service in Israel: Challenges and Ramifications, Memorandum159, INSS Pp. 49-60.[Hebrew]

Golan, Oren and Eyal Ben-Ari 2017 Armed Forces, Cyberspace and Global Images: The Official Website of the Israeli Defense Forces. Armed Forces and Society. 44(2): 280-300. Haltiner, Karl W. and Tibor Szvircsev Tresch 2009 From Conscription Based Defense to Volunteer-Based Constabulary Force: European Defense Integration and Mission Change as Driving Factors for the End of Conscription in Europe. In Kobi Michael, David Kellen and Eyal Ben-Ari (eds.) The Transformation of the World of War and Peace Support Operations. Pp. 39-52. Westport Conn.: Praeger. 
Harel-Shalev, Ayelet \& Daphna-Tekoah, Shir 2019. Breaking the Binaries in Security

Studies: A Gendered Analysis of Women in Combat. Oxford University Press.

Helman, Sara 1997: Militarism and the Construction of Community. Journal of Political and Military Sociology. 25:305-32.

Jarvenpaa, Pauli 2016 Preparing for the Worst: Conscription and the Reserve Forces in the Nordics. Tallin: International Centre for Defence and Security.

Kama, Amit 2012 Parading Pridefully in the Mainstream: Gay and Lesbian Immersion in the Civil Core. In (Guy Ben-Porat and Eyal Ben-Ari (eds) The Contradictions of Israeli Citizenship. London: Routledge. Pp. 180-201.

Kosonen, Jarkko, Alisa Puustinen, and Teemu Tallberg 2019 Saying No to Military Service - obligation, killing and inequality as experienced problems in conscription-based military in Finland. Journal of Military Studies 8:46-57.

Lachmann, Richard 2013 Mercenary, Citizen, Victim: The Rise and Fall of Conscription in the West. In John A. Hall and Sinisia Malesevic (Eds): Nationalism and War. Cambridge: Cambridge University Press. Pp. 44-69.

Levy, Y. (2011). The Decline of the Reservist Army. Military and Strategic Affairs, $3(3): 63-74$.

Levy, Yagil 2012 Military Hierarchies and Collective Action. In (Guy Ben-Porat and Eyal Ben-Ari (eds) The Contradictions of Israeli Citizenship. London: Routledge. Pp. 40-61. Levy, Yagil 2019 Preface. In Yagil Levy, Nir Gazit, Rinat Moshe and Alona Harness (eds.) The Army and the Market Society in Israel. Raanana: Open University of Israel Press. Pp. 9-10. (Hebrew)

Levy, Yagil, Edna Lomsky-Feder, and Noa Harel. 2007. From “Obligatory Militarism” to “Contractual Militarism": Competing Models of Citizenship. Israel Studies 12(1):127-48. Limor Yoav and Koren Ziv 2018, Snapshot, Tel Aviv: Zmoora Bitan -Dvir. [Hebrew] Limor, Yoav, 2020. The Ghosts, Israel Hayom, (20, August, 2020) [Hebrew] 
Lipschitz, Yaakov 2015 Conscription or Recruitment via the Market - Economic Aspects. In Meir Elran and Gabi Sheffer (eds.) Military Service in Israel: Challenges and Ramifications. Tel Aviv: Institution of National Security Studies. Pp. 21-6. (Hebrew) Livio, Oren, 2012. “Avoidance of Military Service in Israel: Exploring the Role of Discourse,” Israel Studies Review 27(1), pp. 78-97.

Lomsky-Feder, Edna 1998: As if There Was No War: The Life Stories of Israeli Men. Jerusalem: Magnes. (Hebrew)

Lomsky-Feder, Edna and Eyal Ben-Ari 2012 Managing Diversity in Context: Unit Level Dynamics in the Israel Defense Forces. Armed Forces and Society 39(2):193 - 212. Lomsky-Feder, Edna and Orna Sasson-Levy 2018 Women Soldiers and Citizenship in Israel. New York: Routledge.

Mohadin, Aamna. 2018. "European countries are quietly bringing back the draft," Quartz (3 July, 2018) <https://qz.com/1318379/france-joins-sweden-and-lithuania-in-bringing-backmandatory-national-service/> (accessed: August, 2020).

N.A. (N.D). "Maslul Schakim,” IDF Conscription site (MEITAV) <https://www.mitgaisim.idf.il/\%D7\%AA\%D7\%A4\%D7\%A7\%D7\%99\%D7\%93\%D7\%99 \%D7\%9D/\%D7\%9E\%D7\%A1\%D7\%9C\%D7\%95\%D7\%9C\%D7\%A9\%D7\%97\%D7\%A7\%D7\%99\%D7\%9D/> (Accessed: August, 2020) [Hebrew]. N.A. (N.D). “Tochnit Havatzalot,” IDF Conscription Site (MEITAV) <https://www.mitgaisim.idf.il/\%D7\%AA\%D7\%A4\%D7\%A7\%D7\%99\%D7\%93\%D7\%99 \%D7\%9D/\%D7\%AA\%D7\%9B\%D7\%A0\%D7\%99\%D7\%AA\%D7\%97\%D7\%91\%D7\%A6\%D7\%9C\%D7\%95\%D7\%AA/> (Accessed: August, 2020) [Hebrew].

Or Abramson and Others vs. The Minister of Defense and Others, Israel Supreme Court Case 5923/19; 34/20. 
Panu Poutvaara \& Andreas Wagener, 2011 published in: Christopher J. Coyne and Rachel L. Mathers (eds.), The Handbook on the Political Economy of War, Edward Elgar Publishing, 2011. https://www.iza.org/publications/dp/4429/the-political-economy-ofconscription. (Accessed 10 May 2020).

Peled, Yoav 2012 The Rise and Fall of Liberal Nationalism. In (Guy Ben-Porat and Eyal Ben-Ari (eds) The Contradictions of Israeli Citizenship. London: Routledge. Pp. 278-91. Perez, Merav 2018 State, resistance, and class reproduction: the case of military service avoidance in Israel, Critical Military Studies, 1-23.

Pion-Berlin, David 1992 Military Autonomy and Emerging Democracies in South America. Comparative Politics 25(1):83-102.

Rein, Yonat and Eyal Ben-Ari Forthcoming. The Israel Reserve Law: The Duality of Reservists and Transformed Military Autonomy. Armed Forces and Society

Rivnai Bahir, Shira \& Meidad Avidar, 2017. “Alternative vs. Canonical Discourses Regarding Military Service in Israel”, Res Militaris, Issue n5, November 2017.

Rodman, David 2017 Unmanned Aerial Vehicles in the Service of the Israeli Air Force:

"They will soar on wings like eagles". Middle East Review of International Affairs, 14(3):77-84.

Rosenhek, Zeev 2012 Dynamics of Inclusion and Exclusion in the Israeli Welfare State: State-Building and Political Economy. In (Guy Ben-Porat and Eyal Ben-Ari (eds) The Contradictions of Israeli Citizenship. London: Routledge. Pp. 63-85.

Rosman, Elisheva. 2020. An undergraduate school for the nation: the effect of military service on veterans' social perceptions. Nations and Nationalism, 26(4):1033-1053.

Safrai, Mordechai 2018 Legitimating Military Growth and Conscription: The Yom Kippur Mechanism. Armed Forces and Society 45(3):491-510.

Safrai, Motty 2019 When Neo-Liberalism Meets the "People's Army": Change to the People's Army as Reflected in Transformations of the Model of Regulars' Service. In 
Yagil Levy, Nir Gazit, Rinat Moshe and Alona Harness (eds.) The Army and the Market Society in Israel. Raanana: Open University of Israel Press. Pp. 98-124. (Hebrew)

Shamir, Eitan and Eyal Ben-Ari 2016 (with Eitan Shamir) The Rise of Special Operations Forces: Generalized Specialization, Boundary Spanning and Military Autonomy. Journal of Strategic Studies 41(3):1-37.

Shavit, Michal (2017) Media Strategy and Military Operations in the 21st Century. London: Routledge.

Sher, Yehudit, Ariel Vainer and Eyal Ben-Ari. 2011. The IDF in Operation Cast Lead: From Hybrid Wars to Combinatorial Militaries. In Efraim Lavi (ed) Civil-Military Relations in Israel: Implications for Decision-Making about Issues of War and Peace. Tel Aviv University: Tami Steinmetz Center for Peace Studies. Pp. 87-98. (Hebrew) Stadler, Nurit and Eyal Ben-Ari 2003: Other Worldly Soldiers? Ultra-Orthodox Views of Military Service in Contemporary Israel. Israel Affairs 9(4):17-48.

Stadler, Nurit, Edna Lomsky-Feder and Eyal Ben-Ari 2008 Fundamentalism's Challenges to Citizenship: The Haredim in Israel. Citizenship Studies 12 (3):215-231.

Tarabar, Danko \& Joshua C. Hall, 2016 Explaining the worldwide decline in the length of mandatory military service, 1970-2010 Public Choice 168(1):55-74.

Tiargan, Roni, 2015. Different Reflections of the Motivation to Serve in the IDF, in Elran Meir and Sheffer Gabi (ed), Military Service in Israel: Challenges and Ramifications, Memorandum159, INSS. Pp. 61-76 [Hebrew]

Tishler Asher and Sasson Hadad, June 19, 2011, Conscription versus Professional Army: The Impact of Recruiting Model in Israel's Military Power, Caesarea Forum To Outline National Economic Policy, 84-96. [Hebrew]

Tresch, Tibor Szvirczev. 2011. The Transformation of Switzerland's Militia Armed Forces and the Role of the Citizen in Uniform, Armed Forces and Society 37(2):239-260. 
Weiss, Erica. 2017. Competing Ethical Regimes in a Diverse Society: Israeli Military

Refusers. American Ethnologist 44(1):52-64.

Williams, Cindy. 2005. From Conscripts to Volunteers. Naval War College Review, 58(1).

https://digital-commons.usnwc.edu/cgi/viewcontent.cgi?article=1951\&context=nwc-

review. (Accessed 10 May 2020).

Notes

${ }^{1}$ For example: Irondelle, 2003.

${ }^{2}$ In this respect, we agree with Krebs' (2005) observation that militaries adopt more liberal manpower policies due to socio-political considerations.

${ }^{3}$ Shhakim is a program preparing potential conscripts for telecommunication roles in intelligence postings.

Those found suitable, are invited to participate in a pre-service program that does not count toward service time. After completing the course, they must sign on for additional service (ranging from six months to two extra years). Women must also sign on for 32 months of service, equal to men's compulsory service. (For further information: N.A. "Maslul Shchakim," IDF site).

${ }^{4}$ Havatzalot is the flagship program of the Intelligence Corps. Those selected for the program complete a B.A. program in Middle Eastern Studies and Political Science together will telecommunication skills. They must sign on for a minimum of six years of additional service and attend officers' course. (For further information: N.A. "Tochnit Havatzalot," IDF site).

${ }^{5}$ Such as: Or Abramson and Others vs. Minister of Defense and Others, Israel Supreme Court Case 5923/19; $34 / 20$.

${ }^{6}$ Stein Helge Kingsrød, e- mail to author, September 3, 2020. 